\title{
Root and Shoot Growth Responses to Phosphate Fertilization in Container-grown Plants
}

Timothy K. Broschat and

Kimberly A. Klock-M oore

AdDitional INDEX WORDS. Dypsislutescens, Spathi phyllum, I xora, L ycopersi con esaulentum, Tagetes erecta, C apsiaum annuum, Pentaslanceolata, root to shoot ratio

Su m m ARY. A reca palms [D ypsis slutescens (H . Wendl.) Beentje \& J. D ransf.], spathiphyllums (Spathi phyllum Schott. 'Figaro'), ixoras (I xora L. 'N ora G rant'), tomatoes (Lycopersicon esaulentum Mill. 'Floramerica'), marigolds (Tagetes erecta L. 'Inca Gold'), bell peppers (Capsiaum annuum L. 'Better Bell'), and pentas [Pentas lan ceolata (Forssk.) D eflers. 'C ranberry'] were grown in a pine bark-based potting substrate and were fertilized weekly with $0,8,16,32$, or $64 \mathrm{mg}$ ( $1.0 \mathrm{oz}=28,350 \mathrm{mg})$ of $P$ per pot. Shoot, and to a much lesser extent, root dry weight, increased for all species as weekly $\mathbf{P}$ fertilization rate was increased from 0 to $8 \mathrm{mg} /$ pot. As $P$ fertilization was increased from 8 to $64 \mathrm{mg} / \mathrm{pot}$, neither roots nor shoots of most species showed any additional growth in response to increased P. R oot to shoot ratio decreased sharply as $P$ fertilization rate was increased from 0 to $8 \mathrm{mg} /$ pot, but remained relatively constant in response to further increases in $P$ fertilization rate.

A

mong the nutrient elements required for plant growth, phosphorus has been associated with growth of meristem-

U niversity of Florida, FLREC, 3205 C ollege Avenue, Ft. L auderdale, FL 33314

Florida Agricultural Experiment Station journal series R-07109. Theauthorswish to thank TheodoraFrohne, I raidaR afols, and Susan Thor for their assistance in this project. The cost of publishing this paper was defrayed in part by the payment of page charges. U nder postal regulations, this paper thereforemust behereby marked advertisement solely to indicate this fact. 
T able 1. Planting and harvest dates for seven species of container-grown plants.

\begin{tabular}{lcc}
\hline Species & Planting date & H arvest date \\
\hline Areca palm & $29 \mathrm{Mar} .1999$ & 27 July 1999 \\
Bell pepper & $19 \mathrm{Apr} .1999$ & $26 \mathrm{M}$ ay 1999 \\
Ixora & $29 \mathrm{M}$ ar. 1999 & 6 July 1999 \\
M arigold & $19 \mathrm{Apr} .1999$ & 2 June 1999 \\
Pentas & $19 \mathrm{Apr} .1999$ & 7 June 1999 \\
Spathiphyllum & $29 \mathrm{Mar} .1999$ & 3 Aug. 1999 \\
Tomato & $29 \mathrm{Mar} .1999$ & $26 \mathrm{Apr} .1999$ \\
\hline
\end{tabular}

atic tissue and in particular, root growth (Tisdale et al., 1985; Wittwer, 1969;). There is a widespread belief that $P$ fertilization stimulates root growth over shoot growth. In a review on root to shoot ratiosin trees, $\mathrm{H}$ arris (1992) cited seven examples of books or manuals on tree care that either stated or implied that $P$ primarily promotes root growth and $\mathrm{N}$ shoot growth. H owever, none of these references provided any experimental datato support this dogma. The belief that $P$ fertilization preferentially stimulates root growth over shoot growth hasled to the practice of providing high $\mathrm{P}$ content starter fertilizers to promote rapid transplant establishment of horticultural plants (Wittwer, 1969), again without experimental evidence that high $\mathrm{P}$ fertilizers are beneficial to root growth. There is some evidence that P-starved roots grow and branch profusely when $P$ is added to their environment (D rew and Saker, 1978), but nothing to indicate that roots of previously P-starved plants grow any faster than their shoots, or that addition of higher levels of $P$ increases either root or shoot growth rates above that of minimally P-sufficient plants. Indeed, Anghinoni and Barber (1980) showed that $P$ starvation, rather than its provision, increased root to shoot dry weight ratiosin corn (Zea maysL.), and D ufault (1985) found that root to shoot ratios decreased with increasing $P$ fertilization levels in celery [A pium graveolens var. dulce (M ill.) Pers.] transplants. O ther studies showed that $P$ had no effect on either root growth or root to shoot ratio in a wide range of plants ( $D$ ufault and Schultheis, 1994; M elton and D ufault, 1991; Weston and Zandstra, 1989; Yeager and Wright, 1981). The purpose of this study was to determine the root and shoot growth responses to $P$ fertilization in a wide range of container-grown horticultural plants.

\section{Materials and methods}

Liners of areca palm, and plugs of
'Figaro' spathiphyllum, 'N ora Grant' ixora, 'Floramerica' tomato, 'I ncaG old' marigold, 'Better Bell' bell pepper, and 'C ranberry' pentas were transplanted into 3.8-L (1-gal) plastic containers using a 5 pine bark : 4 sedge peat : 1 sand (by volume) substrate amended with M icromax (ScottsC $0, M$ arysville, $\mathrm{O}$ hio) at $890 \mathrm{~g} \cdot \mathrm{m}^{-3}\left(1.5 \mathrm{lb} / \mathrm{yard}^{3}\right)$ and dolomitic limestone at $7.1 \mathrm{~kg} \cdot \mathrm{m}^{-3}(12 \mathrm{lb} /$ $\left.\mathrm{yard}^{3}\right)$. T en replicateplants of each treatment were arranged in a completely randomized design within each species. Each pot received $50 \mathrm{ml}(16.9 \mathrm{fl} . \mathrm{Oz})$ of a liquid fertilizer solution weekly containing $80 \mathrm{mg}(0.0028 \mathrm{oz}$.) of both $\mathrm{N}$ and $\mathrm{K}$ from $\mathrm{NH}_{4} \mathrm{NO}_{3}$ and $\mathrm{K}_{2} \mathrm{SO}_{4}$ and 0 , $8,16,32$, or 64 mg of $\mathrm{P}$ from $\mathrm{N} \mathrm{aH}{ }_{2} \mathrm{PO}_{4}$.

Plants were grown in an opensided greenhouse with a maximum PPFD of about $1800 \mu \mathrm{E} \cdot \mathrm{m}^{-2} \cdot \mathrm{s}^{-1}$ except for thespathiphyllumswhich weregrown under shade (about $400 \mu \mathrm{E} \cdot \mathrm{m}^{-2} \cdot \mathrm{s}^{-1}$ ) within the same greenhouse. All pots received about $2 \mathrm{~cm}$ (0.8 inches) of water daily from overhead irrigation. All plants for a particular species were harvested when most of the plants reached a marketable size for a \#1 container. Planting and harvest dates for each species are shown in Table 1 . Shoots were cut off at soil level and rootswere rinsed free of potting substratebeforedrying at $60^{\circ} \mathrm{C}\left(140{ }^{\circ} \mathrm{F}\right)$ for dry weight determination. $D$ ata were analyzed by regression analysis using Table Curve 2D (SPSS, Chicago, III.) with the simplest modelshaving thehighest $R^{2}$ valuesand tightest confidence intervals being selected.

\section{Results and discussion}

Plants of all species wereextremely stunted when grown with no supplemental $P$, and shoot dry weight increased sharply for all species as $\mathrm{P}$ applied per pot was increased from 0 to 8 mg/ week (Figs. 1 and 2; T able 2). For most species, shoot dry weight showed little or no increase as $P$ fertilization rate was increased from 8 to $64 \mathrm{mg} /$ week.
Shoot dry weight of bell peppers and arecapal msappeared to decreaseslightly as $P$ fertilization rate was increased beyond $16 \mathrm{mg} /$ week.

Root dry weight remained relatively constant for tomatoes and marigolds as $P$ was increased from 0 to 64 mg/ week (Fig. 1). H owever, bell peppers, pentas, ixoras, areca palms, and spathiphyllums showed a slight increase in root dry weight as $P$ was increased from 0 to $8 \mathrm{mg} /$ week (Figs. 1 and 2). For ixoras and spathiphyllums, root dry weight increased slightly at higher $P$ fertilization rates, but areca palm root dry weight began to decrease at $P$ fertilization rates of $16 \mathrm{mg} /$ week or higher (Fig. 2).

Root to shoot ratiosdecreased with increasing $\mathrm{P}$ fertilization for tomatoes and marigolds (Fig. 1). Root to shoot ratio was highly variable for marigolds. For all other species, however, root to shoot ratios decreased sharply as $P$ was increased from 0 to $8 \mathrm{mg} /$ week, but remained relatively constant as $P$ was further increased from 8 to $64 \mathrm{mg} /$ week. These data demonstrate that

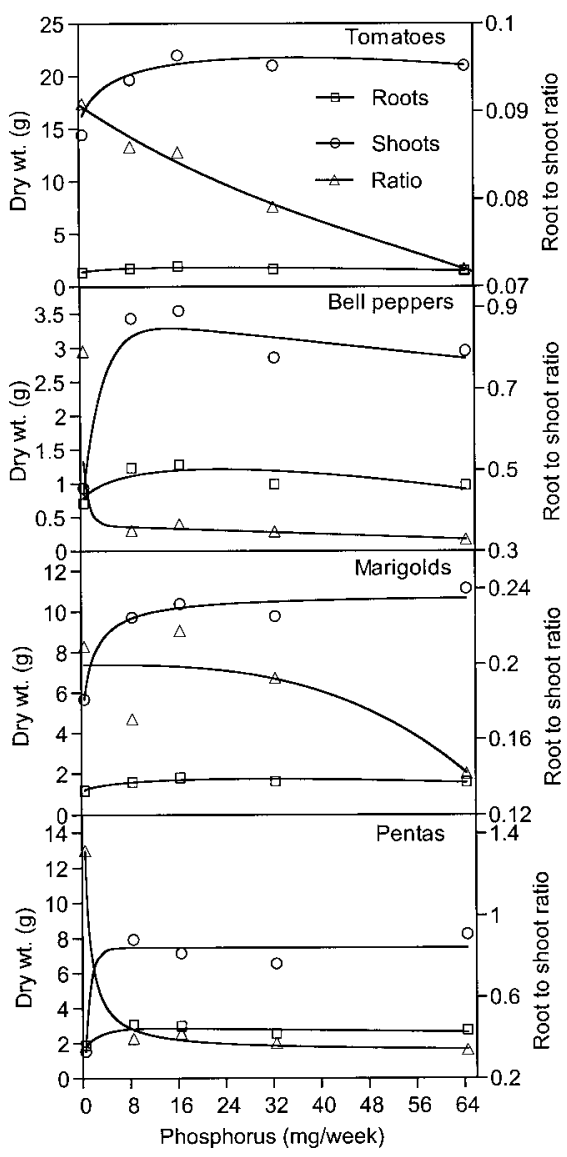

Fig. 1. R oot and shoot growth responses to $P$ fertilization in tomatoes, bell peppers, marigolds, and pentas. $28.35 \mathrm{~g}=1.0 \mathrm{oz}$. 


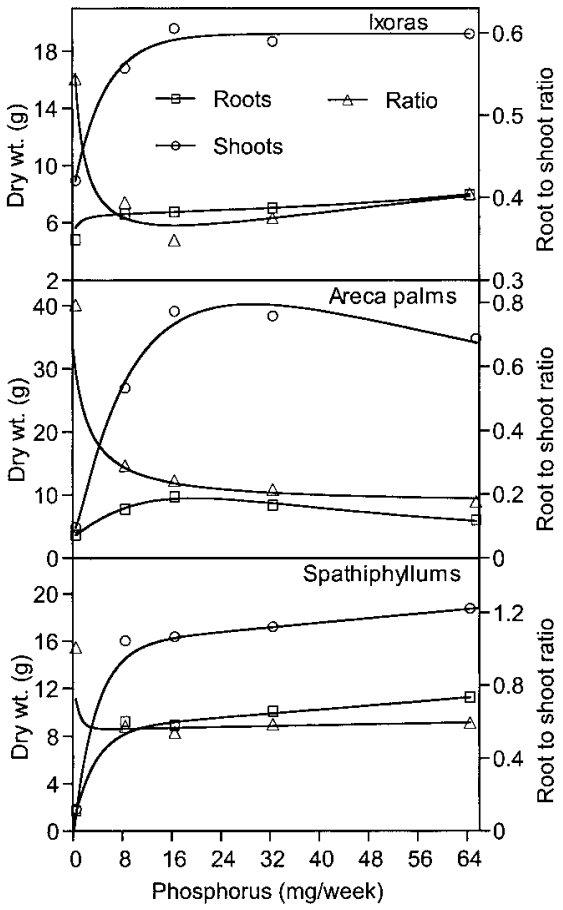

Fig. 2. Root and shoot growth responses to $P$ fertilization in ixoras, areca palms, and spathiphyllums. $28.35 \mathrm{~g}=1.0 \mathrm{oz}$.

increasing $P$ fertilization rates does not promote root growth as popularly believed. I $n$ fact, only at deficiency level sof substrate $P$ did roots of most species respond positively to increased $P$ fertilization, and even then root response was less than that of the shoots. $\mathrm{H}$ igher levels of $P$ resulted in little or no increase in root growth for these species. Similarly, shoot growth responded most dramatically to increasing $P$ fertilization only at deficiency levels. Further additions of $\mathrm{P}$ generally did not result in additional shoot growth for most speciesand may even havesuppressed shoot growth slightly at the highest levels (64 mg P/ week) for areca palms and bell peppers. Root to shoot ratio, the best indicator of differential root growth response, decreased or remained thesame as $\mathrm{P}$ fertilization rates were increased for all species tested. These results are in agreement with earlier studies on other crops (Anghinoni and Barber, 1980; D ufault, 1985; D ufault and Schultheis, 1999; Melton and Dufault, 1991; Weston and Zandstra, 1989; Yeager and Wright, 1981)

\section{Conclusions}

O ur data suggest that most container-grown plants require only minimal amounts of $P$ for optimum growth and that applications of high $P$ fertilizers will not promote either root or shoot growth in plants as popularly believed. In fact, relative root growth actually decreased or stayed the same with increased $P$ fertilization. Thus there is no advantage to using high $P$ fertilizers in the production of these crops.

\section{Literature cited}

Anghinoni, I. And S.A. Barber. 1980. Phosphorus influx and growth characteristics of corn roots as influenced by phosphorussupply. Agron. J. 72:685688.

D rew, M.C. and L.R. Saker. 1978. N utrient supply and the growth of the seminal root system in barley. III. Compensatory increase in growth of lateral roots, and in rates of phosphate uptake, in response to localized supply of phosphate. J. Expt. Bot. 29:435-451.

D ufault, R.J . 1985. Relationship among nitrogen, phosphorus, and potassium fertility regimes on celery transplant growth. H ortScience 20:1104-1106.

D ufault, R.J. and J.R. Schultheis. 1994. Bell pepper seedling growth and yield following pre-transplant nutritional conditioning. H ortScience29:999-1001.

H arris, R.W. 1992. Root:shoot ratios. J . Arboricult. 18:39-42.

M elton, R.R. and R.J. Dufault. 1991. Nitrogen, phosphorus, and potassium fertility regimes affect tomato transplant growth. H ortScience 26:141142.

Tisdale, S.I ., W.L. N elson, and J.D. Beaton. 1985 Soil fertility and fertilizers. M acmillan Press, $\mathrm{N}$ ew York.

Weston, L.A. and B.H . Zandstra. 1989. Transplant age and $\mathrm{N}$ and $\mathrm{P}$ nutrition effects on growth and yield of tomatoes. H ortScience 24:88-90.

Wittwer, S.R. 1969. Regulation of phosphorus nutrition of horticultural crops. H ortScience 4:320322.

Yeager, T.H . and R.D. Wright. 1981. Influence of nitrogen and phosphorus on shoot:root ratio of I lex crenata Thunb. 'H elleri'. H ortScience 16:564-565.

Table 2. Regression equations for root, shoot, and root to shoot ratio responses to increasing $P$ fertilization in seven species of container-grown plants.

\begin{tabular}{lclrc}
\hline Species & Response & Regression equation & $\mathbf{R}^{2}$ & F \\
\hline Tomato & Roots & $\mathrm{y}=1.34-(2.58 \mathrm{E}-2) \mathrm{x}+0.22 \mathrm{x}^{0.5}$ & 0.867 & $6.49^{*}$ \\
& Shoots & $\mathrm{y}=15.67-0.17 \mathrm{x}+2.05 \mathrm{x}^{0.5}-1.24 \mathrm{e}^{-\mathrm{x}}$ & 0.959 & $7.89^{* *}$ \\
& Ratio & $\mathrm{y}=9.06 \mathrm{E}-2-(4.83 \mathrm{E}-4) \mathrm{x}+(4.9 \mathrm{E}-6) \mathrm{x}^{2}-(2.99 \mathrm{E}-8) \mathrm{x}^{3}$ & 0.989 & $31.28^{* * *}$ \\
Bell pepper & Roots & $\mathrm{y}=0.74-(2.35 \mathrm{E}-2) \mathrm{x}+0.21 \mathrm{x}^{0.5}$ & 0.757 & $4.11^{*}$ \\
& Shoots & $\mathrm{y}=3.51-(1.02 \mathrm{E}-2) \mathrm{x}-2.57 \mathrm{e}^{-\mathrm{x}}$ & 0.965 & $27.52^{* * *}$ \\
& Ratio & $\mathrm{y}=0.36-(5.41 \mathrm{E}-4) \mathrm{x}+0.43 \mathrm{e}^{-\mathrm{x}}$ & 0.999 & $814.43^{* * *}$ \\
Marigold & Roots & $\mathrm{y}=1.17-0.02 \mathrm{x}+0.21 \mathrm{x}^{0.5}$ & 0.890 & $8.13^{* *}$ \\
& Shoots & $\mathrm{y}=5.67+1.56 \mathrm{x}^{-1}$ & 0.956 & $21.85^{* * *}$ \\
& Ratio & $\mathrm{y}=0.20-(2.16 \mathrm{E}-7) \mathrm{x}^{3}$ & 0.660 & $5.64^{*}$ \\
Pentas & Roots & $\mathrm{y}=3.0-(5.64 \mathrm{E}-3) \mathrm{x}+1.11 \mathrm{e}^{-\mathrm{x}}$ & 0.879 & $7.28^{*}$ \\
& Shoots & $\mathrm{y}=-(10.61 \mathrm{E}-\mathrm{x})+7.466$ & 0.942 & $48.90^{* * *}$ \\
& Ratio & $\mathrm{y}=0.982 \mathrm{x}^{-1}+0.33$ & 0.995 & $617.79^{* * *}$ \\
Ixora & Roots & $\mathrm{y}=6.24+(2.78 \mathrm{E}-6) \mathrm{x}^{3}+0.12 \mathrm{x}^{0.5}-1.4 \mathrm{e}^{-\mathrm{x}}$ & 0.999 & $117,058.31^{* * *}$ \\
& Shoots & $\mathrm{y}=19.22-10.29 \mathrm{E}-(\mathrm{x} / 5.05)$ & 0.987 & $77.32^{* * *}$ \\
& Ratio & $\mathrm{y}=0.69-0.21 \ln \mathrm{x}+(3.24 \mathrm{E}-2)(\ln \mathrm{x})^{2}+(6.3 \mathrm{E}-4)(\ln \mathrm{x})^{3}$ & 0.990 & $31.83^{* * *}$ \\
Areca palm & Roots & $\mathrm{y}=3.56-0.27 \mathrm{x}+(1.8 \mathrm{E}-6) \mathrm{x}^{3}+2.44 \mathrm{x}^{0.5}$ & 0.956 & $24.95^{* * *}$ \\
& Shoots & $\mathrm{y}=4.39-\mathrm{x}+11.84 \mathrm{x}^{0.5}$ & 0.974 & $37.38^{* * *}$ \\
& Ratio & $\mathrm{y}=0.79+1.26 \mathrm{x}^{-1}$ & 0.999 & $1125.37 * * *$ \\
Spathiphyllum & Roots & $\mathrm{y}=8.69+(4.04 \mathrm{E}-2) \mathrm{x}-6.99 \mathrm{e}^{-\mathrm{x}}$ & 0.996 & $249.49^{* * *}$ \\
& Shoots & $\mathrm{y}=15.62+(4.9 \mathrm{E}-2) \mathrm{x}-13.77 \mathrm{e}^{-\mathrm{x}}$ & 0.999 & $74,079.09^{* * *}$ \\
& Ratio & $\mathrm{y}=0.56+(6.13 \mathrm{E}-4) \mathrm{x}+0.45 \mathrm{e}^{-\mathrm{x}}$ & 0.992 & $124.28^{* * *}$ \\
\hline
\end{tabular}

